\title{
Influence of row spacing on yield and yield attributes of black gram (Vigna mungo L. Hepper) variety Chakwal in Balochistan
}

Amanullah ${ }^{1}$, Shafique Ahmed ${ }^{2}$, Muhammad Iqbal Jakhro ${ }^{1 *}$, Munir Ahmed $^{1}$, Nadeem Sadiq ${ }^{1}$, Muhammad Yaqub ${ }^{3}$ and Sher Ahmed ${ }^{1}$

1. PARC Balochistan Agricultural Research and Development Centre Brewery Road, Quetta-Pakistan

2. PARC Agriculture Research Institute Turbat BARDC-Pakistan

3. PARC Agriculture Research Institute Khuzdar BARDC-Pakistan

*Corresponding author's email: iqbal.jakhro@gmail.com

Citation

Amanullah, Shafique Ahmed, Muhammad Iqbal Jakhro, Munir Ahmed, Nadeem Sadiq, Muhammad Yaqub and Sher Ahmed. Influence of row spacing on yield and yield attributes of black gram (Vigna mungo L. Hepper) variety Chakwal in Balochistan. Pure and Applied Biology. Vol. 7, Issue 2, pp413-418. http://dx.doi.org/10.19045/bspab.2018.70051

Received: 05/01/2018 Revised: 21/03/2018

Accepted: $24 / 03 / 2018$

Online First: 31/03/2018

\section{Abstract}

The experiment was carried out in Balochistan Agricultural Research and Development Centre Brewery Road, Quetta during Kharif 2016 to check the effect of four different row spacings i.e., $25,30,35$ and $40 \mathrm{~cm}$ on influence of row spacing on yield and yield attributes of black gram (Vigna mungo L. Hepper) variety Chakwal in Balochistan under semi-arid climate. Results revealed that except of total dry matter all the parameters including yield and yield components were significant at ( $\mathrm{P}>0.05)$ influenced by different row spacing. Maximum (709) grain yield $\mathrm{kg}$ $\mathrm{ha}^{-1}$ was received from the treatment $3(35 \mathrm{~cm}$ row spacing) followed by treatment $-4(40 \mathrm{~cm}$ row spacing) which produced (663) grain yield $\mathrm{kg} \mathrm{ha}^{-1}$ while the minimum (429) grain yield $\mathrm{kg} \mathrm{ha}^{-1}$ was gave by the treatment-1 $(25 \mathrm{~cm}$ row spacing) respectively. Results more revealed that treatment-3 (35 cm row spacing) and treatment-4 (40 cm row spacing) produced (16) and (12) total pods was recorded per plant vastly significantly and nice preformed simultaneous with grain yield. Therefore, researchers obtained differential response in relation to row spacing and selecting high yielding cultivars of mash bean.

Keywords: Black gram; Chakwal; Row spacing; Variety

\section{Introduction}

Black gram (Vigna mungo L. Hepper) is an important pulse crop, which belongs to popular plant family papillionaceae. This crop is origin from India, and is famous by the name of black gram. The black gram not only fixing free atmospheric Nitrite, but also supplement the soil with Nitrogen for the growth of future crops [1]. The economic product of black gram is seed grain, which is a good source of dietary protein. This crop can be successfully grown on loam soil [2]. Furthermore this crop improve the plant essential nutrients in soil and it is a great source of protein for human health. Chemical analysis of black gram seed shown 
that it contains $20-24 \%$ protein, $2.1 \%$ oil, 1 $2 \%$ fats, carbohydrates and a fair amount of vitamin-A and B [3]. It has an excessive potential to improve protein deficiency in human beings by providing a low cost protein. In Balochistan 1700 ha black gram is grown as a Kharif crop with a total yield of production 1200t/ $706 \mathrm{~kg}$ per ha. Black gram grow in Pakistan 75.4 percentage and the Punjab is major gram producing province contribution about 80 percent. While in Balochistan 5.12 percentage in cultivated black gram. [4]. Balochistan is the largest province of Pakistan. Grounded on climatic conditions, researchers obtained differential response of Black gram in relation to row spacing. In Balochistan Black gram is grown as a Kharif of area is 798 ha with a maximum production of $639 \mathrm{t}$ [4]. The variance in seed rates is of excessive significance for the crop and further yield characteristics. It has been evaluated that farmers use lesser seed rates especially for Black gram and chickpea. Scientist studied also discovered that supreme of the growth and yield contributing characteristics are considerably and clearly correlated with the seed grain yield of various crop plants viz., Black gram $[5,6]$, chickpea [7], mung bean [8], soybean [9] and sunflower [10]. Close row spacing improved dry matter yield compared with the far row spacing. A benefit of closed row spacing is extra medium plant positioning that leads to augmented canopy leaf area enlargement and more light capture earlier in the season [11]. These variations in canopy development rise crop progress level and dry matter increase [12]. The finest seed level in pulses is the greatest essential feature for getting better yields. However, $[13,14]$. Therefore, this study was began to determine the most favorable seed rate in order to high the seed yield of Black gram.

\section{Materials and methods}

This field trial on Black gram (Vigna mungo
L. Hepper) was established out in $3^{\text {rd }}$ June in Kharif season, 2016 at Quetta Balochistan. Four treatments of different row spacing i.e. 25, 30, 35 and $40 \mathrm{~cm}$ were kept. Experiment was laid out in a Randomized Complete Block Design (RCBD) with a plot size of 10 x $20 \mathrm{~m}$ with three replications. Used Diammonium phosphate (DAP) at the sowing time and Nitrogen in the form Urea at the flowering and pod formation stages. An improved Black gram variety Chakwal were sown with hand drill machine @ 15 kg per ha then imbedded deepness of 3-4 cm. First irrigation was applied after 20 days and Second irrigation at the time of flower initiation and Third irrigation was applied at the pod formation. All the recommended cultural practices were equally followed to maintain a healthy crop stand in the trial. The data in terms of Plant height, number of branches plant ${ }^{-1}$, number of pods plant ${ }^{-1}$, number of seed pod $^{-1}$ and Plant density was recorded at the maturity and three samples of $1 \mathrm{~m}^{2}$ from each treatment were randomly collected in terms of total dry matter, grain yield at the harvesting [15]. All observations were analyzed by using the Fisher's analysis of variance techniques and difference among treatments means were compared by using the statistical package named Statistix 8.1 computer software LSD test at $p<0.05$ [16].

\section{Results and discussion Plant height}

Results showed in table 1 that in response to effect of row spacing, the plant height values were statistically significant with each other. Maximum (18) $\mathrm{cm}$ plant height was recorded in treatment $3(35 \mathrm{~cm}$ row spacing) whereas minimum (13) cm plant height was produced by treatment-1 $(25 \mathrm{~cm}$ row spacing). In this connection, [17, 18] observed plant height increase with high densities and early planting dates in their experiments. However, moderate row spacing viz., 30 and $35 \mathrm{~cm}$ numerically produced the highest plant height. Similar 
results were also obtained by [19], but are in contradiction with those explained by [20].
They stated that increase in row spacing decreases the plant height in black gram.

Table 1. Effect of row spacing on yield and yield attributes of Black gram variety Chakwal

\begin{tabular}{|c|c|c|c|c|c|c|c|}
\hline Treatments & $\begin{array}{c}\text { Plant } \\
\text { height } \\
\text { (cm) }\end{array}$ & $\begin{array}{c}\text { No. } \\
\text { branches } \\
\text { /plant }\end{array}$ & $\begin{array}{c}\text { No. } \\
\text { pods/ } \\
\text { plant }\end{array}$ & $\begin{array}{c}\text { No. } \\
\text { seed/pod }\end{array}$ & $\begin{array}{c}\text { Plant } \\
\text { density }\end{array}$ & $\begin{array}{c}\text { TDM } \\
\text { kg/ ha-1 }\end{array}$ & $\begin{array}{c}\text { Grain } \\
\text { Yield } \\
\text { kg/ha }\end{array}$ \\
\hline $\begin{array}{c}\text { T1=25 cm row } \\
\text { spacing }\end{array}$ & $13 \mathrm{C}$ & $3 \mathrm{C}$ & $6 \mathrm{C}$ & $4 \mathrm{C}$ & $20 \mathrm{~A}$ & 2406 & $429 \mathrm{C}$ \\
\hline $\begin{array}{c}\text { T2=30cm row } \\
\text { spacing }\end{array}$ & $16 \mathrm{~B}$ & $4 \mathrm{~B}$ & $9 \mathrm{~B}$ & $6 \mathrm{~B}$ & $17 \mathrm{AB}$ & 2275 & $564 \mathrm{~B}$ \\
\hline $\begin{array}{c}\text { T3=35 cm row } \\
\text { spacing }\end{array}$ & $18 \mathrm{~A}$ & $6 \mathrm{~A}$ & $16 \mathrm{~A}$ & $7 \mathrm{~A}$ & $14 \mathrm{~B}$ & 2170 & $709 \mathrm{~A}$ \\
\hline $\begin{array}{c}\text { T4=40 cm row } \\
\text { spacing }\end{array}$ & $\begin{array}{c}17 \mathrm{AB} \\
*\end{array}$ & $\begin{array}{c}5 \mathrm{AB} \\
*\end{array}$ & $\begin{array}{c}12 \mathrm{AB} \\
* *\end{array}$ & $\begin{array}{c}6 \mathrm{AB} \\
*\end{array}$ & $\begin{array}{c}12 \mathrm{C} \\
*\end{array}$ & $\begin{array}{c}2023 \\
\mathrm{NS}\end{array}$ & $\begin{array}{c}663 \mathrm{AB} \\
*\end{array}$ \\
\hline
\end{tabular}

Values followed by different letters within same column are significant at alpha $=0.050$

\section{Number of branches plant ${ }^{-1}$}

Results indicated in table 1 that in response to effect of row spacing, the Number of branches/plan were statistically significant with each other. Maximum (6) Number of branches /plan was produced by treatment-3 (35cm row spacing) whereas minimum (3) Number of branches /plan was gave by treatment-1 $(25 \mathrm{~cm}$ row spacing finding and also obtained by $[21,22]$.

\section{Number of pods plant ${ }^{-1}$}

Results showed in table 1 that in response to effect of row spacing highly significant increased the quantity of pods each plant. Maximum (16) Amount of pods/plant was observed in treatment-3 (35 cm row spacing) however least (6) Sum of pods plant $^{-1}$ was produced by treatment-1 $(25 \mathrm{~cm}$ row spacing). It might be due to greater number of plants per unit row length, which might have adversely affected the pod development, hence, pods formation were comparatively less than that of low seeding rate which resulted in greater competition for light, space and nutrients. Similar results were obtained by [23] who reported that all the yield contributing characters were favorably affected by planting geometry.

\section{Number of seeds pod $^{-1}$}

Number of seeds per pod in table 1 showed significant response to effect of row spacing, the maximum (7) number of seeds per pod was recorded from the treatment- $3(35 \mathrm{~cm}$ row spacing) while the minimum (4) number of seeds/pod gave by the treatment-1 $(25 \mathrm{~cm}$ row spacing).

\section{Plant density}

The data on plant density are subjected to analyzed and significant found among the treatments. The table 1 revealed that maximum (20) Plant density was obtained by treatment-1 (25 cm row spacing) whereas the minimum (12) Plant density was produced by treatment 4 (40 cm row spacing). Seed yield and yield components of mungbean are markedly influenced by planting density. The farmers usually grow mungbean without maintaining proper planting density. They hesitate to grow mungbean in rows, although row planting facilitates easy intercultural operations resulting in higher yield [24]. Row planting with appropriate planting density can help ensure optimum plant population unit ${ }^{-1}$ area of mungbean thereby increasing the yield [25].

\section{Total Dry Matter kg/ha}

Data on Total dry matter (TDM) $\mathrm{kg} / \mathrm{ha}$ 
showed nonsignificant in table 1. Maximum (2406) total dry matter $\mathrm{kg} / \mathrm{ha}$ was recoded from treatment- $1(25 \mathrm{~cm}$ row spacing) followed by treatment-2 (30 cm row design) gave $2275 \mathrm{~kg}$ per ha whereas the minimum $2023 \mathrm{~kg} \mathrm{ha}^{-1}$ was obtained in treatment-4 (40 $\mathrm{cm}$ row spacing) respectively. Contracted row spacing improved dry matter yield equated with the broader row spacing. A benefit of slim row spacing is extra internal plant typography that principals to amplified canopy leaf range advance and superior light interruption former in the period. [26]. These variations in canopy foundation upturn crop development proportion and dry matter amassing [27-29].

\section{Grain yield kg ha-1}

Data regarding mean values of that grain yield $\mathrm{kg} \mathrm{ha}^{-1}$ responded in significant in response to effect of row spacing in table 1 . However, numerically a maximum (709) grain yield $\mathrm{kg} \mathrm{ha} \mathrm{ha}^{-1}$ were obtained from treatment-3 (35 cm row spacing) while the minimum 429 grain yield $\mathrm{kg} \mathrm{ha}{ }^{-1}$ were observed in treatment-1 ( $25 \mathrm{~cm}$ row spacing). [29-31] believe that yield of chickpea increases with increasing density form 33 to 54 plants $\mathrm{m}^{2}$. Row space arrangement had noteworthy consequence on yield modules. Generating expressively upper seed yield components in broader spacing is in accordance with the outcomes of best of the former research. [31]. There is a trend that as row spacing increases, grain yield also increases. In this respect present results are in conformity with the results obtained by some workers [32, 33].

\section{Conclusions}

Concluded that Chakwal variety of black gram $35 \mathrm{~cm}$ row spacing and $40 \mathrm{~cm}$ row spacing producing very greatly significantly and better preforming simultaneous with grain yield. The current revision designated that row spacing affected yield mechanisms of Black gram in environmental climatic of Quetta Balochistan.

\section{Authors' contributions}

Designed \& idea the experiments: Amanullah, Implemented the experiments: $S$ Ahmed, M Ahmed \& N Sadiq, Analyzed the Data: Amanullah \& M Yaqoob, Contributed reagents/Materials/Analysis tools: S Ahmed, Wrote the paper: Amanullah \& MI Jakhro.

\section{References}

1. Bhattacharyya PN \& Jha DK (2012). Plant growth-promoting rhizobacteria (PGPR): emergence in agriculture. World $J$ of Microbiol and Biotech 28(4): 13271350.

2. Ghafoor A, Ahmad Z \& Qayyum A (2003). Black Gram (Vignamungo L. Hepper) Germplasm Catalogue. Plant Genetic Research Program. PARC/JICA, Islamabad, Pakistan. pp 75-80.

3. Zia-Ul-Haq M, Ahmad S, Amarowicz R \& Ercisli S (2013). Compositional studies of some pea (Pisum sativum L.) seed cultivars commonly consumed in Pakistan. Ital J Food Sci 25(1): 295-302.

4. Anonymous (2002-2003). Agricultural Statistics Balochistan. Statistical Wing. Directorate General Agriculture (Ext.): Balochistan, Quetta. pp 1-2.

5. Mahmood-ul-Hassan, Zubair M \& Ajmal $S$ (2003). Correlation and path coefficient analysis in some promising lines of mash bean (Vigna mungo). Pak J Biol Sci 6(4): 370-372.

6. Khan MD, Khalil IH, Khan MH \& Ikramullah K (2004). Genetic divergence and association for yield and related traits in mash bean. Sarhad J Agric 20: 555-561.

7. Arshad M, Bakhsh A \& Ghafoor A (2004). Path coefficient analysis in chickpea (Cicer arietinum L.) under rainfed conditions. Pak J Bot 36(1): 7581.

8. Siddique M, Malik MFA \& Awan SI (2006). Genetic divergence, association and performance evaluation of different 
genotypes of mungbean (Vigna radiata). Int J Agric \& Biol 8(6): 793-795.

9. Malik MFA, Ashraf M, Qureshi AS \& Ghafoor A (2007). Assessment of genetic variability, correlation and path analyses for yield and its components in soybean. Pak J Bot 39(2): 405-413.

10. Vahedi B, Gholipouri A \& Sedghi M (2010). Effect of planting pattern on radiation use efficiency, yield and yield components of sunflower. Rec Res Sci Tech 2(2): 38-41.

11. Weber CR, Shibles RM \& Byth DE (1966). Effect of plant population and row spacing on soya bean development and Production. Agron J 5(8): 99-102.

12. Andrade FH, Calvino P, Cirilo A \& Barbieri P (2002). Yield responses to narrow rows depend on increased radiation interception. Agron $J$ 94: pp. 975-980.

13. Steel RGD, Torrie JH \& Dickey DA (1997). Principles and procedures of Statistics, Biometrical Approach. $3^{\text {rd }}$ Ed. McGraw Hill Book Co. New York (USA).

14. Rahemi KA, \& Soltani A (2005). Allometric relationships between leaf area $\mathrm{m}$ and vegetative qualities in plant chickpea. In proceedings of the first national conference on pulse in Iran. 2021 Nov. Research center for plant sciences. Ferdowsi University of Mashhad, Mashhad (Iran).

15. Rezvani MP \& Sadeghi SR (2005). Study of the effects on yield and morphological characteristics of chick pea ILC 3279 under climatic conditions of Neishabur. In proceeding of the First National Conference on pluse in Iran. 2021 Nov. Research Center for Plant Sciences Ferdowsi University of Mashhad, Mashhad (Iran).

16. Statistix, 2006. Analytical Software. Statistix 8.1 User's Manual. Analytical Software, Tallahssee (Florida).
17. Goldani M, Bagheri A \& Nezmi A (2000). Study of the effect of planting date on phenology and morphology of chick pea varieties. In proceeding of $6^{\text {th }}$ Iranian congress of crop production and Plant Breeding. 3-6. Babolsar, University of Mazandaran (Iran).

18. Ihsanullah FH, Taj H, Akbar A, Basir A $\&$ Noorullah (2002). Effect of row spacing on the agronomic traits and yield of mung bean \{Vigna radiate (L.) Wilczek\}. Asian J Plant Sci 1(4): 328329.

19. Mehmud M, Chiezey UF, Ahmed MK \& Rofia I (1997). Effect of different levels of phosphorus fertilizers and intra row spacing on the gram yield, growth and yield components of black gram \{Vigna mungo (L.) Hepper $\}$. Discovery and Innovation 9(1-2): 47-51.

20. Yilmaz N (2003). The effects of seed rate on yield and yield components of soybean (Glycine max L. Merill). Pak J Biol Sci 6(4): 373-376.

21. Tonçer Ö \& Kizil S (2004). Effect of seed rate on agronomic and technologic characters of Nigella sativa L. Int J Agric \& Biol 6(3): 529-532.

22. Gama BPS, Inanaga S, Tanaka K \& Nakazawa R (2007). Physiological response of common bean (Phaseolus vulgaris L.) seedling to salinity stress. African J Biotech 6(2): 79-88.

23. Nazir MS, Nadeem MA, Gill MB \& Ahmad R (1991). Effect of planting geometry on yield and yield components of lentil (Lens culinaris). Sarhad J Agric 7(2): 7-10.

24. Shibles RM \& Weber CR (1966). Interception of solar radiation and dry matter production by various soybean planting patterns. Crop Sci 6: 55-59.

25. De Bruin JL \& Pedersen P (2008). Effect of row spacing and seeding rate on soybean yield. Agron J 100: 704-710. 
26. Bullock D, Khan S \& Rayburn A (1998). Soybean yield response to narrow rows is largely due to enhanced early growth. Crop Sciences 38(4): 1011-1016.

27. Pezeshkpur P, Daneshvar M \& Ahmadi A (2005). The effect of plant density on agronomical properties, leaf chlorophyll and light penetration to shading floor of white chickpea variety. In proceeding of the first national conference on pulse in Iran. 20-21 Nov. Res Center for Plant Sci Ferdowsi university of Mashhad (Iran).

28. Shams KS, kobra'e R \& Zangeneh, R (2005). Study of the effect of planting density on the trend of grain filling, yield and yield components of 3 chickpea varieties under Kermanshah conditions. In proceedings of the first national conference on pulse in Iran. 20-21 Nov. Res Center for Plant Sci Ferdowsi University of Mashhad (Iran).

29. Ahmadian AM, Sobhani A \& Malek, M (2005). Study of density effect on yield and its components of chickpea varieties under northern Khorassan dry farming conditions. In proceeding of the first national conference on pulse in Iran. 2021 November. Research center for plant sciences. Ferdowsi university of Mashhad (Iran).

30. Sabbaghpur H (2002). Study of the most suitable plant density and planting date new Hashem variety of chickpea in Golestan province. In proceeding of the 7th Iranian Crop Sciences Congress, Karaj, Iran.

31. Açıkgoz E, Karasu SM, Tongel A, Wietgrefed O, Bilgili G, Oz U, Albayrak M, Turan SZM \& Goksoy AT (2009). Forage soybean production for seed in Mediterranean environments. Field Crops Res 110(3): 213-218.

32. Borah UK (1994). Response of black gram varieties to row spacing under rainfed conditions. Annals Agric Res 15(4): 516-517.

33. Mishra M \& Mishra A (1995). Effect of fertilizers, weed control and row spacing on summer black gram (Phaseolus mungo). Indian J Agron 40(3): 434-438. 